\title{
Premature mortality from cardiovascular disease and diabetes in the Caribbean and associations with health care expenditure, $2001-2011$
}

\author{
Ahmed Razavi, ${ }^{1}$ Ian Hambleton, ${ }^{2}$ T. Alafia Samuels, ${ }^{2}$ Natasha Sobers, ${ }^{3}$ \\ and Nigel Unwin ${ }^{1}$
}

Suggested citation

Razavi A, Hambleton I, Samuels TA, Sobers N, Unwin N. Premature mortality from cardiovascular disease and diabetes in the Caribbean and associations with health care expenditure, $2001-2011$. Rev Panam Salud Publica. 2018;42:e179. https://doi.org/10.26633/RPSP.2018.179

\begin{abstract}
Objective. To examine the historical trends of premature death due to cardiovascular disease and diabetes mellitus (CVD-DM) in the Caribbean and to identify any associations between these trends and health care expenditure.

Methods. Death data were obtained from the World Health Organization Mortality Database; population data, from the United Nations World Population prospects; and health care expenditure data, from the World Bank. In all, 17 Caribbean countries had mortality data; however, only 11 had both mortality and health care expenditure data available. The analyses explored country-level trends in age-standardized CVD-DM mortality rates using 3-year moving averages from 1995 - 2014 for women and men. Associations between secular mortality rate change and health care expenditure were considered.

Results. CVD-DM mortality rates ranged from $10.7-247.1$ per 100000 , with a mean of 92.3 and standard deviation of 47.6. Of the 17 countries, 12 showed a reduction in premature CVD-DM mortality in both men and women, with others either showing no improvement or increases. Mortality rates for men were 1.46 times higher than for women. On average, there was a $68 \%$ increase in health care expenditure, with a $15.4 \%$ fall in CVD-DM mortality in women and $4.9 \%$ in men. Mixed effects modelling demonstrated a weak association between health care expenditure and declining CVD-DM mortality for both women $-0.006(95 \% C I=-0.014-0.001)$ and men $-0.008(95 \% C I=-0.017-0.001)$.

Conclusions. Findings suggest that progress has been made to reduce premature CVD-DM related mortality in a number of Caribbean countries. Differences between countries may be partly related to differences in health care system performance, although further research that considers confounders is needed.
\end{abstract}

Keywords Cardiovascular diseases; diabetes mellitus; mortality; health expenditures; Caribbean Region.

\footnotetext{
George Alleyne Chronic Disease Research Centre, Caribbean Institute for Health Research, University of the West Indies, Bridgetown, Barbados. Faculty of Medical Sciences, University of the West Indies, Bridgetown, Barbados.
}

Medical Research Council Epidemiology Unit, University of Cambridge, Cambridge, ingdom. Send correspondence to Ahmed Razavi, ahmed.razavi@mrc-epid.cam. ac.uk
According to the World Health Organization (WHO), 39.5 million or $70 \%$ of the 56.4 million deaths that occurred globally in 2015 were due to 
non-communicable diseases (NCDs), of which, $44 \%$ were among those 0 69 years of age $(1,2)$. NCDs make up a substantial proportion of preventable, premature mortality across low- and middle-income countries (LMICs), as well as high-income countries. In the Caribbean, $76 \%$ of premature deaths among adults $(30-69$ years of age) were caused by NCDs (3).

Cardiovascular disease accounted for 17.7 million deaths globally in 2015, approximately $45 \%$ of NCD-related mortality. More than $75 \%$ of deaths due to cardiovascular disease occur in LMICs (4). Diabetes mellitus can lead to morbidity and mortality, both directly and indirectly, especially as a risk factor for cardiovascular disease. The higher a person's blood glucose level, the higher the risk of mortality from cardiovascular disease (5). Cardiovascular disease is a major cause of mortality in people with diabetes, accounting for nearly one-half of all deaths (6). To avoid misclassification of diabetes and cardiovascular disease, this paper considers both together, an approach also used by others (7).

Deaths from cardiovascular disease and diabetes mellitus (CVD-DM) are known to be partially preventable through health system interventions. By intervening to reduce the prevalence of underlying risk factors for CVD-DMobesity, physical inactivity, smoking, high cholesterol, and high blood pressure-or by improving treatment for CVD-DM, mortality can be curtailed. For example, in the United States of America, a combination of effective health care and public health interventions has resulted in decreasing mortality from coronary heart disease (8). Also, in the United States, the likelihood of a person with diabetes dying from diabetesrelated causes declined by $40 \%$ in 2000 - 2010. This decline is partially due to better management of diagnosed diabetes, including glucose, lipid, and blood pressure control, and prevention of diabetes-related complications, such as amputations and renal failure (9).

Reduced mortality from CVD-DM could be a major contributor to meeting Sustainable Development Goal 3 (10): reduce premature (30 - 69 years of age) death from noncommunicable diseases by one-third by 2030. WHO has a similar target of reducing premature, noncommunicable disease mortality, including CVD-DM, by $25 \%$ by 2025 (11).
The aim of this study was to examine the historical trends of premature death due to CVD-DM in the Caribbean and to identify any associations between these trends and health care expenditure. The hypothesis was that disparities in trends are partially related to differences in health system performance. The implications of these findings should be important to future research.

\section{MATERIALS AND METHODS}

\section{Data sources}

The WHO Mortality Database (12) was used to generate age-standardized mortality rates for men and women for each Caribbean country with data available. The database is a compilation of annual reports from WHO Member States on the number of registered causes of death, by age and sex. To ensure consistent practices, only reports using the International Classification of Disease $10^{\text {th }}$ edition (ICD10) classification system were extracted. This resulted in data for 1995 - 2014.

To generate age-standardized rates for each sex, the United Nations World Population database (13) was used to identify the age, sex structure, and population of each country. Population figures are based on interpolating forward from past census data, adjusted based births, deaths, fertility, and migration data for each country. Detailed age-sex breakdowns were not available for countries with populations below 90000 . Health care expenditure per capita was extracted from the World Bank database (14) and was measured in inflationadjusted US\$ (year 2000) with purchasing power parity. This was generated using national health accounts data and adjusting figures based on the population and inflation. This provided an indicator for health care expenditure while controlling for varying inflation and population changes among countries.

\section{Study countries}

The researchers attempted to obtain data for all Caribbean island nations (according to the United Nations M49 Standard Area Codes for Statistical Use), as well as countries with historical and cultural ties to the Caribbean that are also Caribbean Community and Common Market (CARICOM) Members States, i.e., Belize, Guyana, and Suriname (15).
All available data was extracted from various databases, and age-standardized rates were generated for each year and country for which data was available. As shown in the Supplementary File, it was possible to generate rates for 17 Caribbean countries.

\section{Statistical analysis}

The WHO Mortality Database was used to identify links between causes and CVD-DM (ICD-10 classification: E10 - E14, I20 - I28, I34 - I38, I42 - I69). Misclassification and missing data within death records was adjusted according to methods described elsewhere (16). In summary, deaths due to illdefined causes (R0-R99) were distributed proportionately to other causes, except injuries. Using linear interpolation, missing data for particular years were imputed, where rates were available for at least 1 year before and after the missing value. Missing values beyond the range of the available data were not imputed. Subsequently a 3-year rolling average was generated to smooth out year-onyear variation in death counts related to the relatively small population sizes.

Again, averages were only generated when rates were available for at least 1 year before and after each given year. In comparing health care expenditure data with the trend data, a time period had to be selected for the analysis. Although data was available for some countries for 1995 - 2014, more had data for the 2001 2011, and thus, this was chosen as the study period. To establish trends for each country, age-standardized, sex-specific, mortality rates were calculated for each year and standardized to the World Standard population 2000 (17) for 30 70 years of age to generate a premature CVD-DM mortality rate. Percentage change in CVD-DM mortality was determined for the time period where most data was available (2001 - 2011). This was calculated as the proportional percentage difference between 2001 and 2011 relative to the CVD-DM mortality in 2001. Subsequently, scatter plots of Caribbean-wide and country trends were used to explore disparities in CVD-DM mortality rates and trends. A line of best fit was generated in each graph using locally-weighted scatterplot smoothing (LOWESS). The weighting limited the influence of individual outliers and helped to visually interpret relationships 
with a lot of scatter. Also, 3-point equiplots were created to summarize the mortality data. These showed mortality rates for each country in 2001, 2006, and 2011 on a single line and allowed for a visual comparison of mortality rates between countries over time.

The generated mortality rates were also compared with inflation-adjusted, health care expenditure per capita in US\$ for 11 countries with data available in both databases for 2001 - 2011. The change in CVD-DM mortality from 2001 2011 was compared with the change in health care expenditure for this same period. This was done both visually, using the LOWESS method, and through a mixed effects model, using a random intercept for different countries. The analysis measured the statistical dependence between health care expenditure and premature CVD-DM mortality in these 11 countries. Further mixed effect models were used to explore whether the expenditure/mortality rate relationship changed over time, both year to year and over 5-year periods using interaction terms. The analysis also considered a possible lagged effect between health care expenditure in a given year and the premature CVD-DM mortality rate in the next year. The statistical analysis was performed using Stata ${ }^{\circledR} / \mathrm{MP} 14$ (StataCorp LP, College Station, Texas, United States).

\section{RESULTS}

Age-standardized CVD-DM mortality rates were generated for the 17 Caribbean countries with any available data. Table A in the Supplementary Materials shows data availability for each of the included countries. Across the entire time period, $73.8 \%$ of possible years had data available.

Age-adjusted mortality rates were variable across the Caribbean, ranging from nearly 250 CVD-DM deaths per 100000 population annually among males in Guyana, to just over 10 among females in Martinique. Fourteen of the 17 countries had lower rates among women in 2011 than in 2001; among men, 12 countries had lower rates (Figures 1A and $1 \mathrm{~B})$. The 10-year absolute change in mortality for females ranged from a reduction of 40.6 per 100000 in Guyana to an increase of 4.6 in Grenada. For males, the 10-year change in absolute mortality rates ranged from a reduction of 42.6 per
FIGURE 1A. Age-standardized cardiovascular disease and diabetes mellitus (CVD-DM) mortality rate among women in the Caribbean, 2001, 2006, and 2011

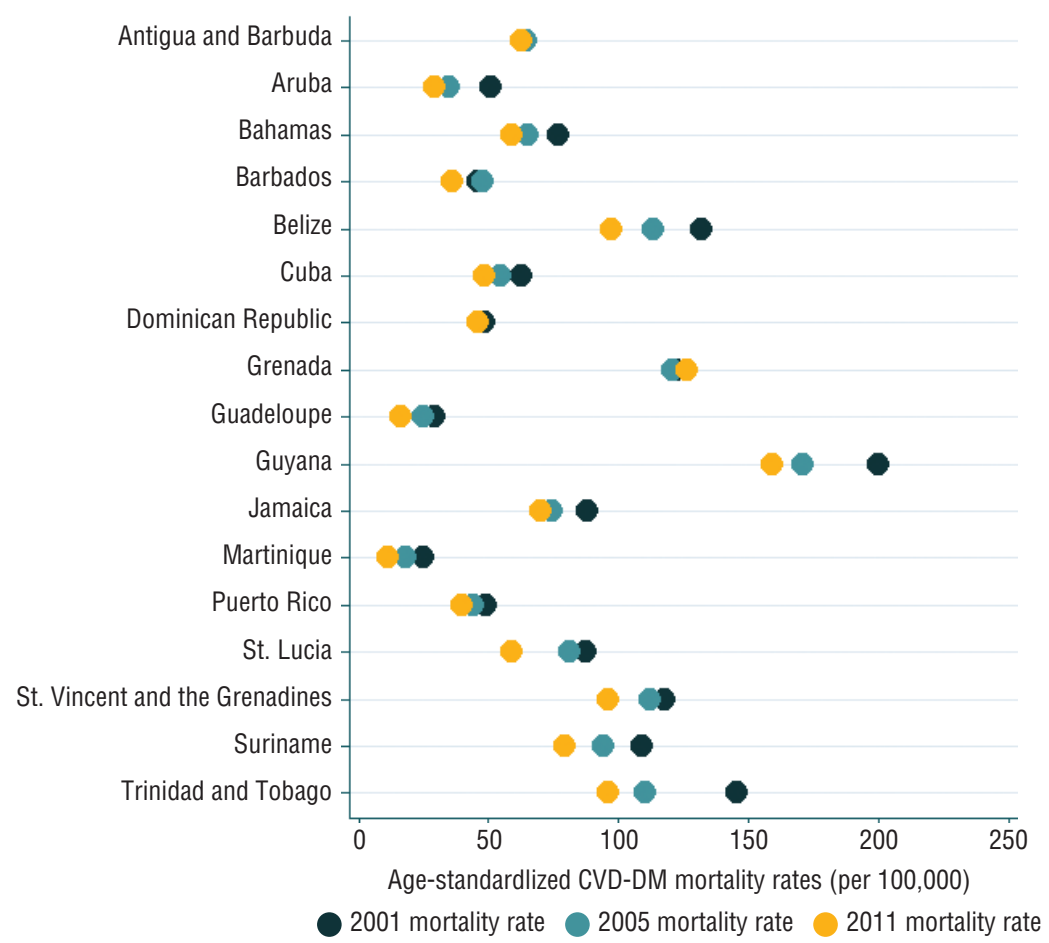

Source: Prepared by the authors from the study results using the WHO Mortality Database.

FIGURE 1B. Age-standardized cardiovascular disease and diabetes mellitus (CVD-DM) mortality rate among men in the Caribbean, 2001, 2006, and 2011

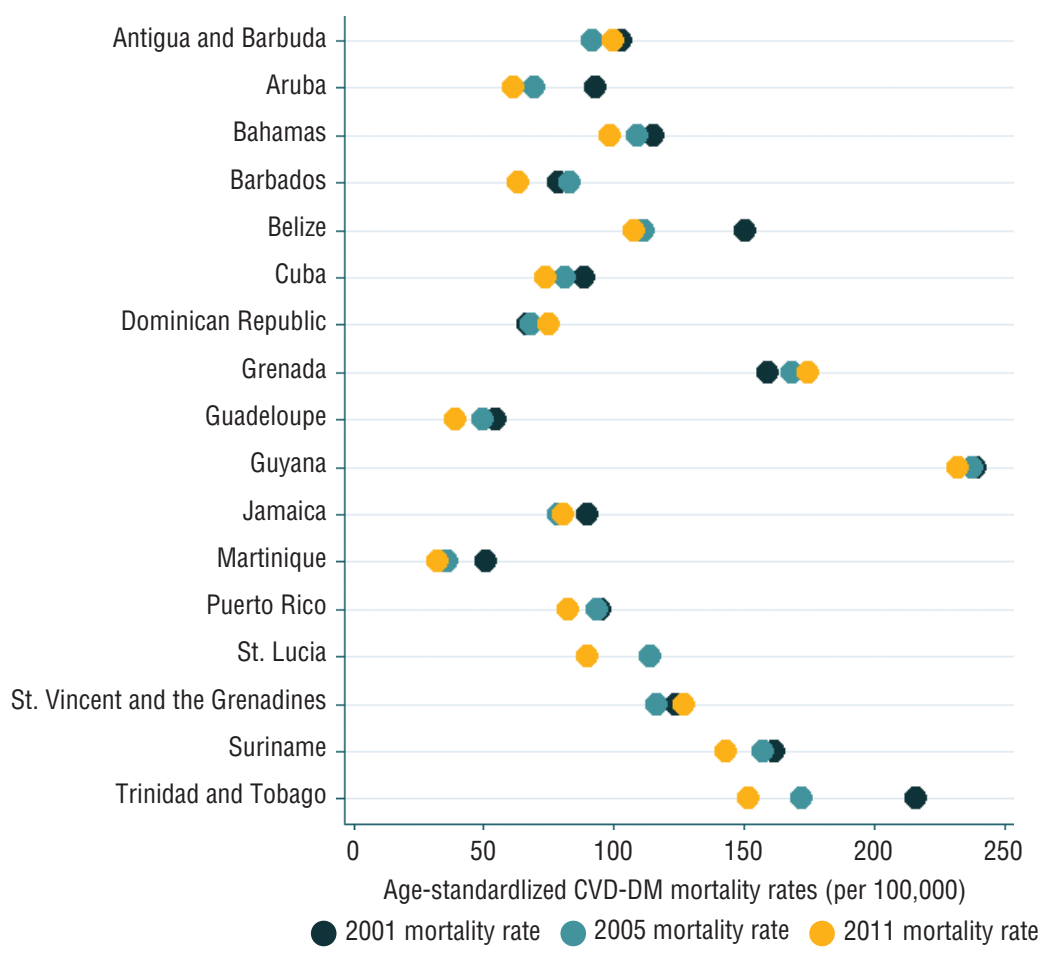

Source: Prepared by the authors from the study results using the WHO Mortality Database and World Bank World Development Indicators database. 
FIGURE 2A. Percentage change (and corresponding ranks based on the absolute mortality rate in the first year of that time period) in premature cardiovascular disease and diabetes mellitus (CVD-DM) mortality rate among women in the Caribbean, 2001 - 2006 compared with 2006 - 2011 (in order of largest percentage decrease in mortality)

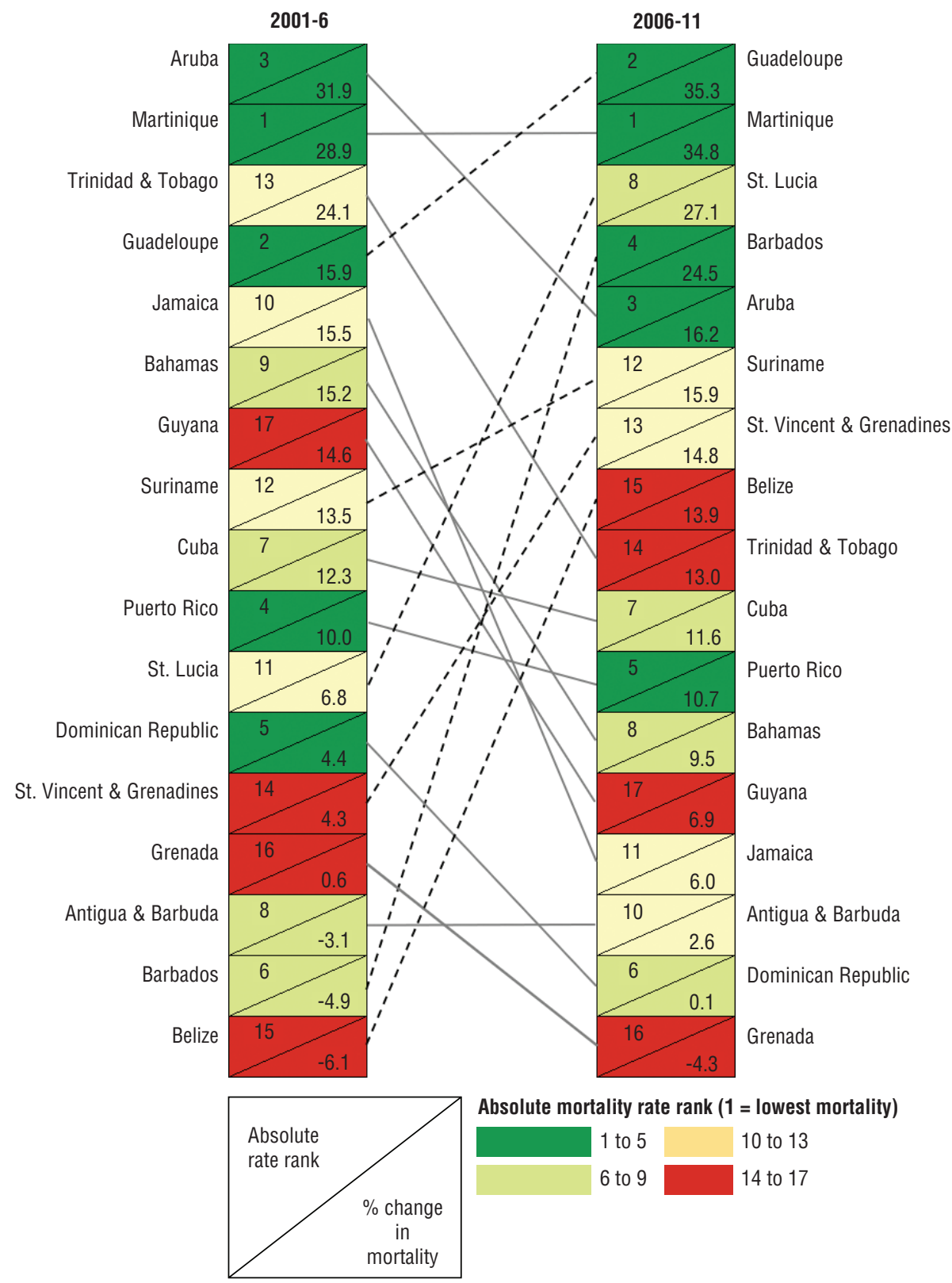

Source: Prepared by the authors from the study results using the WHO Mortality Database.

100000 in Belize to an increase of 16.6 in Grenada. Of the 17 countries, 11 showed decreases for both women and men across the time period; two countries (Jamaica and St. Lucia) showed reductions in CVD-DM mortality for women, but not for men. In the Dominican Republic and Grenada, CVD-DM mortality increased in 2001 - 2011. As shown in Figures $1 \mathrm{~A}$ and $1 \mathrm{~B}$, for most countries, mortality rates were an average of 1.46 times higher among males. Figure 2 demonstrates the percentage change in mortality over two 5-year periods. In both 2001 - 2006 and 2006 - 2011, women experienced a greater reduction in premature CVD-DM mortality. For both men and women, there was a greater reduction in mortality in 2006 - 2011 than in 2001 2006. It is noteworthy that countries with the lowest absolute premature CVD-DM mortality rates also tended to be among the best performing in terms of percentage decline: examples include Aruba, Guadeloupe, and Martinique, especially for women. Of the countries with the highest absolute mortality rates (Figure 2), two stand out as showing very little improvement: Grenada (in women and men) and Guyana (in men). In contrast, two countries with initially high absolute mortality that notably declined for both men and women in 2006 - 2011 were Trinidad and Tobago and St. Lucia.

For countries that had data available, Table 1 shows the change in CVD-DM mortality alongside changes in health care expenditure for 2001 - 2011. Expenditure per capita has risen over time in 11 countries with data available in both databases (six countries did not have expenditure data available). The correlation between change in health care expenditure and change in mortality was assessed using a mixed effects model (Table 2).

Table 2 demonstrates a negative correlation between health care expenditure and premature CVD-DM mortality, but this was not statistically significant. For each additional US $\$$ spent, there is a corresponding decrease in mortality of 0.006 per 100000 population among women and 0.008 among men.

Longitudinal analysis using interaction terms between expenditure and mortality rate demonstrated no significant relationship. Furthermore, analysis of a possible lagged effect between health care expenditure in a given year and premature CVD-DM mortality in the following year revealed no such effect.

mortality declined in 2001 - 2006, and then again, in $2006-2011$.

All of the available data for each country is presented in the Supplementary Materials by males and females separately; data was available for 1995 - 2014, although many countries only had data from the late 1990s onwards.

Most countries appear to have the same trend for males and females, although

\section{DISCUSSION}

Across the Caribbean there are clear disparities in CVD-DM mortality trends among countries and between men and women. Countries had either a clear downward trend, no clear trend, or an upside-down U-shaped trend across the 
FIGURE 2B. Percentage change (and corresponding ranks based on the absolute mortality rate in the first year of that time period) in premature cardiovascular disease and diabetes mellitus (CVD-DM) mortality rate among men in the Caribbean, 2001 2006 compared with $2006-2011$ (in order of largest percentage decrease in mortality)

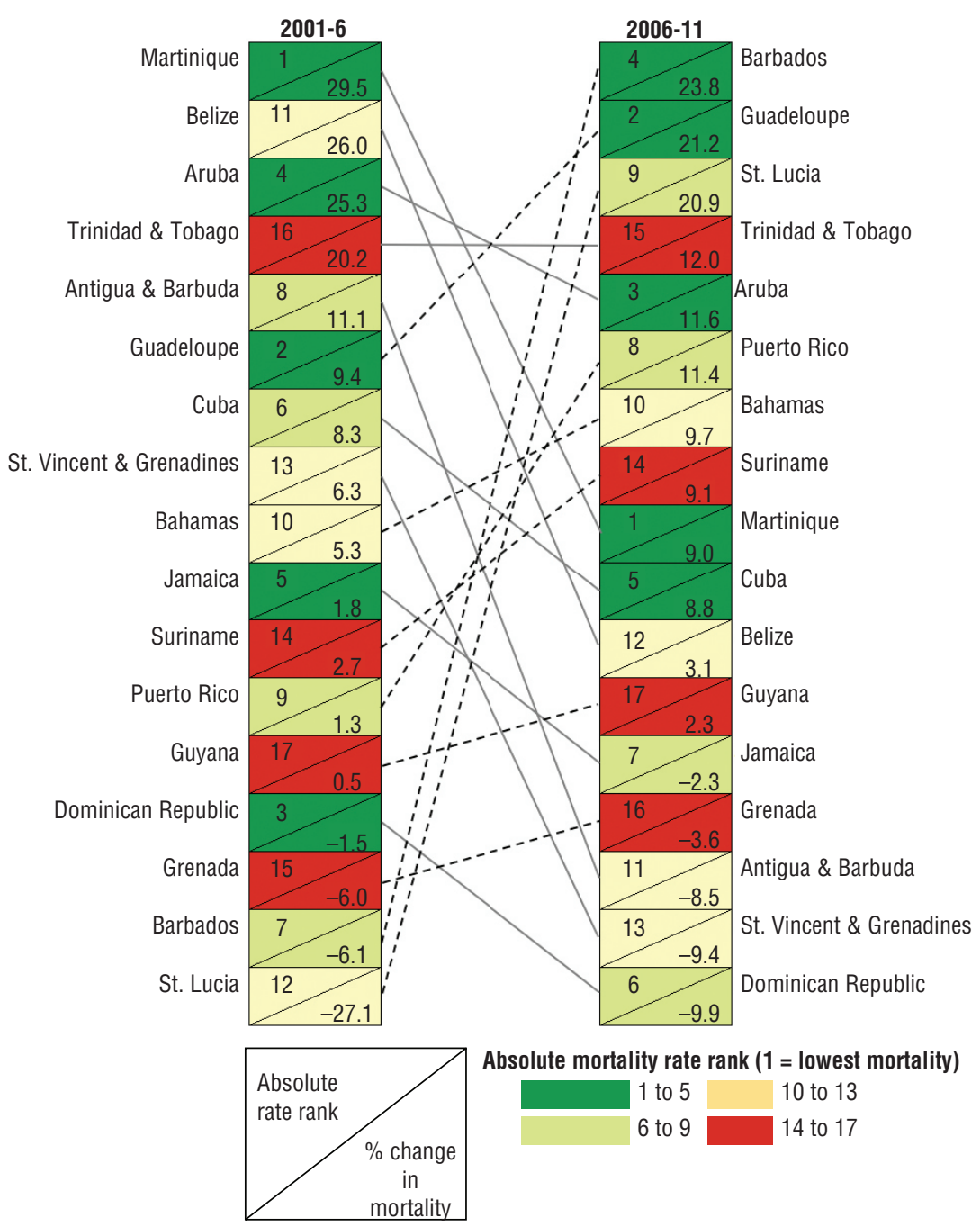

Source: Prepared by the authors from the study results using the WHO Mortality Database.

TABLE 1. Absolute and percentage change in cardiovascular disease and diabetes mellitus (CVD-DM) mortality and health care expenditure in the Caribbean, 2001 - 2011

\begin{tabular}{|c|c|c|c|c|c|c|}
\hline \multirow[t]{2}{*}{ Country } & \multicolumn{2}{|c|}{$\begin{array}{l}\text { Absolute change in } \\
\text { CVD-DM mortality } \\
\text { (per } 100 \text { 000) }\end{array}$} & \multicolumn{2}{|c|}{$\begin{array}{l}\% \text { change in in } \\
\text { CVD-DM mortality }\end{array}$} & \multirow{2}{*}{$\begin{array}{l}\text { Absolute change in } \\
\text { health care } \\
\text { expenditure (US\$) }\end{array}$} & \multirow{2}{*}{$\begin{array}{l}\% \text { change in } \\
\text { health care } \\
\text { expenditure }\end{array}$} \\
\hline & Female & Male & Female & Male & & \\
\hline Antigua and Barbuda & 2.0 & -2.6 & 3.3 & -2.5 & 461 & 69.0 \\
\hline Bahamas & -17.8 & -15.5 & -23.2 & -13.7 & 643 & 59.2 \\
\hline Barbados & -9.2 & -14.5 & -20.3 & -19.9 & 401 & 64.1 \\
\hline Belize & -33.3 & -42.6 & -25.5 & -26.5 & 181 & 69.9 \\
\hline Cuba & -14.0 & -14.4 & -22.5 & -16.4 & 1416 & 240.4 \\
\hline Dominican Republic & 0.7 & 10.3 & 1.6 & 16.6 & 114 & 31.1 \\
\hline Grenada & 4.6 & 16.6 & 3.8 & 10.6 & 125 & 21.3 \\
\hline Guyana & -40.6 & -6.5 & -20.4 & -2.7 & 168 & 68.6 \\
\hline Jamaica & -8.6 & 2.4 & -11.0 & 3.1 & 81 & 22.9 \\
\hline St. Lucia & -25.6 & $1 . .9$ & -30.2 & 2.2 & 329 & 70.0 \\
\hline Suriname & -26.2 & -15.8 & -25.2 & -10.2 & 219 & 32.3 \\
\hline
\end{tabular}

Source: Prepared by the authors from the study results using the WHO Mortality Database and the World Bank World Development Indicators database.
TABLE 2. Mixed effects model for the effect of health care expenditure on cardiovascular disease and diabetes mellitus mortality rate in the Caribbean, $2001-2011$

\begin{tabular}{lccc}
\hline & $\beta$ coefficient & $P$ value & $95 \% \mathrm{Cl}$ \\
\hline Women & -0.006 & 0.11 & -0.014 to 0.001 \\
Men & -0.008 & 0.09 & -0.017 to 0.001 \\
\hline
\end{tabular}

Source: Prepared by the authors from the study results using the WHO Mortality Database and the World Bank World Development Indicators database.

study period. Trends also differed by gender, with the mortality rate for women trending downwards in more countries. We found a weak association (not statistically significant) between health care expenditure and premature CVD-DM mortality in both men and women-supportive of the previous work showing that differences in health system performance can be partially explained by health care expenditure (18).

Disparities in mortality rates and trends in mortality likely have several causes. Caribbean countries have variable national income levels, rates of CVD-DM risk factors, and health care provision that may play a role. There appears to be a clear difference in trends for men and women in some Caribbean countries, which may suggest that women have better health care seeking behavior. As suggested by previous work (19), this may also be related to the fact that levels and patterns of CVD risk factors differ markedly between men and women in the Caribbean (20).

The presence of disparities in trends may suggest that country-level disparities over time may be just as important as Caribbean-wide trends. The variability in reporting mortality to $\mathrm{WHO}$ and issues with coding deaths could potentially attenuate or exaggerate any association. Including a wider range of countries in subsequent work may alleviate this.

There is a positive correlation between increase in health care expenditure and fall in premature CVD-DM mortality across the 11 countries for which data was available, although the relationship is not statistically significant and the sample size was small. While this finding is consistent with the hypothesis that differences in health system performance may contribute to differences among CVD-DM mortality trends, a much more rigorous evaluation would 
be needed to confirm this. For example, ideally, data would be included on trends in CVD risk factors, on trends in the incidence and prevalence of CVD and diabetes (not just its mortality), and on better measures of access to and quality of appropriate health care. It would also be essential to have data on known and potential confounders.

Limitations. This study has some limitations that should be considered. The accuracy of reporting with ICD-10 codes may vary across countries, with misclassifications or inaccuracies perhaps partially responsible for the large variation in rates $(<15$ to $>250$ deaths per 100000 person-years) in the Caribbean. Data for a 20-year time period was analyzed in order to establish trends and limit shortterm variation; however, due to the small populations involved, a natural variation in annual deaths could have a large impact on annual rates, despite calculating 3-year moving averages.

Another limitation was that population age structure data was not available for countries with fewer than 90000 inhabitants, resulting in several being excluded and a small sample of only 17 countries for the analysis of CVD-DM mortality trends and only 11 for the health care expenditure analysis. Health Observatory (GHO) data. Geneva: WHO; 2016.

2. World Health Organization. Premature NCD deaths. Geneva: WHO; 2015. Available from: www.who.int/gho/ncd/mortality_morbidity/ncd_premature_text/ en/ Accessed 10 April 2018.

3. Pan American Health Organization. NCDs in the Caribbean. Available from: www.paho.org/hq/index.php?option=com_content\&view $=$ article\&id=771\&Itemid $=40030 \& l a n g=e n$ Accessed 10 April 2018.

4. World Health Organization. Cardiovascular diseases (CVDs). Geneva: WHO; 2017. Available from: www.who.int/mediacentre/factsheets/fs317/en/ Accessed 26 March 2018.

5. Danaei G, Lawes CM, Vander Hoorn S, Murray CJ, Ezzati M. Global and regional mortality from ischaemic heart disease and stroke attributable to higher-thanoptimum blood glucose concentration: comparative risk assessment. Lancet. 2006;368(9548):1651-9. doi:10.1016/S01406736(06)69700-6.

6. Morrish NJ, Wang S-L, Stevens LK, Fuller $\mathrm{JH}$, Keen H; the WMS Group. Mortality care expenditure data was obtained from the World Bank, which estimates health care expenditures based on available data that can be less accurate for some countries than for others.

\section{Conclusions}

This study highlights the need for further research into why some countries in the Caribbean are outperforming others in terms of preventing noncommunicable disease mortality. The hypothesis that improvements to the health care system (using health care expenditure as a proxy) can reduce CVD-DM mortality is further supported by the findings of this paper; however, factors other than increased expenditure, such as more efficient use of health care resources, provision of free or subsidized CVD-DM medication, and public health interventions to reduce risk factor prevalence may also diminish mortality (21). There is also likely to be a gender determinant to CVD-DM mortality, since findings showed men in the Caribbean to be more likely to die prematurely of CVD-DM than women. This type of research should be used to learn lessons that will guide health systems towards improved public health and clinical interventions that effectively reduce CVD-DM.

\section{REFERENCES}

and causes of death in the WHO multinational study of vascular disease in adiabetes. Diabetol. 2001;44(S2):S14-21. doi:10.1007/PL00002934.

7. Mathers CD, Stevens GA, Boerma T, White RA, Tobias MI. Causes of international increases in older age life expectancy. Lancet. 2015;385(9967):540-8. doi:10.1016/ S0140-6736(14)60569-9.

8. Ford ES, Ajani UA, Croft JB, Critchley JA, Labarthe DR, Kottke TE, et al. Explaining the decrease in U.S. deaths from coronary disease, 1980-2000. N Engl J Med. 2007;356(23):2388-98. doi:10.1056/ NEJMsa053935.

9. Rowley WR, Bezold C, Arikan Y, Byrne E, Krohe S. Diabetes 2030: insights from yesterday, today, and future trends. Popul Health Manag. 2017;20(1):6-12. doi:10.1089/pop.2015.0181.

10. Ordunez P, Prieto-Lara E, Pinheiro Gawryszewski V, Hennis AJM, Cooper RS. Premature mortality from cardiovascular disease in the Americas: will the goal of a decline of " $25 \%$ by 2025 " be met? PLoS One. 2015;10(10):e0141685. doi:10.1371/ journal.pone.0141685.

11. Sacco RL, Roth GA, Reddy KS, Arnett DK, Bonita R, Gaziano TA, et al. The heart of
The overall trend in CVD-DM mortality in the Caribbean has been downwards since the mid-2000s. There is, however, significant inter-country variability, suggesting a potential for further reductions. These findings provide insight into the performance of individual countries, variability between women and men, and the potential association of declining rates with improved health care system performance. The data presented indicate the need for further work to better understand what underlies the trends. It also calls for designing interventions that bring the worst performing countries in line with the best performing in terms of CVD-DM-related premature mortality.

Acknowledgements. We would like to acknowledge Stephen Sharp (Medical Research Council Epidemiology Unit, Cambridge, United Kingdom) for his assistance and guidance in using LOWESS and the mixed methods model.

Conflict of interests. None declared.

Disclaimer. Authors hold sole responsibility for the views expressed in the manuscript, which may not necessarily reflect the opinion or policy of the RPSP/ PAJPH and/or PAHO.
25 by 25: Achieving the goal of reducing global and regional premature deaths from cardiovascular diseases and stroke: a modeling study from the American Heart Association and World Heart Federation. Circulation. 2016;133(23):e674-90. doi:10.1161/CIR.0000000000000395.

12. World Health Organization. WHO mortality database. Geneva: WHO; 2014. Available from: www.who.int/healthinfo/ mortality_data/en/ Accessed 4 May 2017.

13. United Nations. World population prospects 2017. Available from: https://esa. un.org/unpd/wpp/ Accessed 17 April 2018.

14. World Bank. World Bank Open Data. Available from: https://data.worldbank. org/ Accessed 17 April 2018.

15. United Nations Statistics Division. Geographic Regions. Available from: https:// unstats.un.org/unsd / methodology / m49/ Accessed 18 May 2018.

16. Hambleton IR, Jeyaseelan S, Howitt C, Sobers-Grannum N, Hennis AJ, Wilks RJ, et al. Cause-of-death disparities in the African diaspora: exploring differences among shared-heritage populations. Am J Public Health. 2015;105(S3):S491-8. doi:10.2105/AJPH.2015.302676. 
17. Ahmad OB, Boschi-Pinto C, Lopez AD, Murray CJ, Lozano R, Inoue M. Age standardization of rates: a new WHO standard. Available from: www.who.int/healthinfo/ paper31.pdf Accessed on 26 March 2018

18. Evans DB, Tandon A, Murray CJ, Lauer JA. Comparative efficiency of national health systems: cross national econometric analysis. BMJ. 2001;323(7308):307-10. doi:10.1136/BMJ.323.7308.307.

19. Thompson AE, Anisimowicz Y, Miedema B, Hogg W, Wodchis WP, Aubrey-Bassler
K. The influence of gender and other patient characteristics on health careseeking behaviour: a QUALICOPC study. BMC Fam Pract. 2016;17:38. doi:10.1186/ s12875-016-0440-0.

20. Sobers-Grannum N, Murphy MM, Nielsen A, Guell C, Samuels TA, Bishop L, et al. Female gender is a social determinant of diabetes in the Caribbean: a systematic review and meta-analysis. PLoS One. 2015;10(5):e0126799. doi:10.1371/journal. pone.0126799.
21. Sobers-Grannum N. Trends in coronary heart disease mortality in Barbados: 1990 2012 [PhD dissertation]. Barbados: University of West Indies; XXXX

Manuscript received on 7 June 2018. Accepted for publication on 18 July 2018.
RESUMEN

Asociación entre la mortalidad prematura por enfermedades cardiovasculares y diabetes, y el gasto en atención de salud en el Caribe, 2001-2011
Objetivo. Examinar las tendencias históricas de la mortalidad prematura por enfermedades cardiovasculares y diabetes mellitus (ECV-DM) en el Caribe y determinar si hay alguna asociación entre estas tendencias y el gasto en atención de salud.

Métodos. Los datos de mortalidad se obtuvieron de la base de datos sobre mortalidad de la Organización Mundial de la Salud; los datos demográficos, de las Perspectivas de la Población Mundial de las Naciones Unidas; y los datos sobre el gasto en atención de salud, del Banco Mundial. En total, 17 países del Caribe tenían datos sobre mortalidad, pero únicamente 11 tenían datos tanto de mortalidad como del gasto en atención de salud. Se analizaron las tendencias en cada país de las tasas de mortalidad por ECV-DM según la edad usando promedios móviles trienales de 1995 al 2014 para mujeres y hombres. Se tuvieron en cuenta las asociaciones entre el cambio en la tasa de mortalidad secular y el gasto en atención de salud.

Resultados. Las tasas de mortalidad por ECV-DM comprendieron de 10,7 a 247,1 por 100 000, con una media de 92,3 y una desviación estándar de 47,6. De los 17 países, en 12 se encontró una reducción de la mortalidad prematura por ECV-DM tanto en hombres como en mujeres. En el resto de los países, no se observó ni mejora ni aumento. Las tasas de mortalidad en los hombres fueron 1,46 veces más altas que en las mujeres. Por término medio, se produjo un aumento de $68 \%$ del gasto en atención de salud, acompañado de una disminución de 15,4\% en la mortalidad por ECV-DM en las mujeres y de $4,9 \%$ en los hombres. Con este modelo mixto se demostró una asociación débil entre el gasto en atención de salud y la disminución de la mortalidad por ECVDM tanto en mujeres, 0,006 (IC del 95\% IC $=-0,014-0,001$ ), como en hombres, 0,008 (IC del 95\% = -0,017 - 0,001).

Conclusiones. Los resultados indican que se han logrado avances en la reducción de la mortalidad prematura relacionada con ECV-DM en varios países del Caribe. Las diferencias entre los países pueden estar en parte relacionadas con las diferencias en el desempeño de los sistemas de atención de salud, aunque es necesario llevar a cabo más investigaciones donde se tengan en cuenta los factores de confusión.

Palabras clave Enfermedades cardiovasculares; diabetes mellitus; mortalidad; gastos en salud; Región del Caribe. 
RESUMO Objetivo. Examinar as tendências históricas da morte prematura por doença cardiovascular e diabetes mellitus no Caribe e identificar as associações existentes entre as tendências e o gasto com saúde.

\section{Mortalidade prematura por doença cardiovascular e diabetes no Caribe e associações com gasto com saúde, 2001-2011}

Palavras-chave
Métodos. Os dados de mortalidade foram obtidos do Banco de Dados de Mortalidade da Organização Mundial da Saúde (OMS), os dados populacionais dos prospectos de população mundial das Nações Unidas e os dados de gasto com saúde do Banco Mundial. Ao todo, 17 países do Caribe possuíam dados de mortalidade, porém apenas 11 dispunham de dados de mortalidade e de gasto com saúde. Foram analisadas as tendências em cada país das taxas de mortalidade por doença cardiovascular e diabetes padronizadas por idade nos sexos feminino e masculino usando médias móveis de 3 anos de 1995 a 2014. Foram examinadas as associações existentes entre a variação secular da taxa de mortalidade e o gasto com saúde.

Resultados. As taxas de mortalidade por doença cardiovascular e diabetes variaram de 10,7-247,1 por 100 mil (média de 92,3 e desvio padrão de 47,6). Dos 17 países, 12 tiveram redução da mortalidade prematura por doença cardiovascular e diabetes tanto no sexo masculino quanto no feminino, sendo que os outros países não demonstraram melhoria ou aumento. As taxas de mortalidade foi 1,46 vez maior no sexo masculino que no feminino. Em média, houve um aumento de $68 \%$ no gasto com saúde, com uma queda de $15,4 \%$ na mortalidade por doença cardiovascular e diabetes no sexo feminino e $4,9 \%$ no sexo masculino. A modelagem de efeitos mistos demonstrou uma fraca associação entre gasto com saúde e declínio da mortalidade por doença cardiovascular e diabetes tanto no sexo feminino $(-0,006$; IC 95\% $-0,014$ a $0,001)$ quanto no masculino (-0,008; IC 95\% -0,017 a 0,001).

Conclusões. A análise indicou que houve avanços na redução da mortalidade prematura por doença cardiovascular e diabetes em vários países do Caribe. As variações entre os países podem estar relacionadas em parte a diferenças no desempenho dos sistemas de saúde, mas outros estudos são necessários considerando-se os fatores de confusão.

Doenças cardiovasculares; diabetes mellitus; mortalidade; gastos em saúde; Região do Caribe. 